The other publications of the Eugenics Record Office are their octavo bulletins. Of these, eight have appeared, three dealing with the inheritance of insanity. Special attention may be directed to that of Dr. Cotton, the medical director of the New Jersey State Hospital for the Insane (Bulletin No. 8, 1912).

E. H. I. S.

\section{LORD AVEBURY, F.R.S.}

I ORD AVEBURY, whose death on May 28 we 1 recorded last week with regret, was a manysided man, one of those gifted men who, without making any very profound advance in science, yet succeeded in making science acceptable and even welcome to the ordinary man. He was a banker by profession, and an antiquary, a politician, a man of science and of letters by inclination. He was born in London on April 30, I834, the eldest son of Sir John William Lubbock, third baronet. His school was Eton, which, however, he left at a schoolboy age to enter his father's banking business. Throughout his life Lord Avebury, or, as he was for many years better known, Sir John Lubbock - he succeeded his father in I 865 showed a great capacity for steady, plodding work, not only in the City, but in politics, municipal administration, and in scientific and archæological research, and his activities were of the widest.

In I870 Sir John Lubbock was returned for the borough of Maidstone, and he held this seat for ten years. In 1872 he became vice-chancellor of the University of London, and eight years later he was elected member for that university, and for the next twenty years he represented this seat of learning. He was active as a Parliamentarian, taking an especial interest in questions of education and social reform. He made a particularly good university representative, being a man of learning as well as of affairs. Amongst the many good causes he advocated, perhaps the establishment of bank holidays was the one most widely known and the one which will preserve his name the longest. In Igoo he was raised to the peerage as the first Lord Avebury, and it is characteristic of him that he chose a title intimately connected with archæology.

For many years Lord Avebury was a neighbour of Charles Darwin at Down, Kent, and it may have been their friendship that led to his interest in "Ants, Bees, and Wasps"; "The Senses, Instincts, and Intelligence of Animals"; "The Collembola and Thysanura"; "Flowers, Fruits, and Leaves," and in "The Origin and Metamorphoses of Insects," as five of his most illuminating books are entitled. He and his helpers added materially to our knowledge of the habits and instincts of social and other insects, and to our acquaintance with the activity of many forms of vegetable growth. His work, indeed, did much to pave the way for the great interest now taken in insects, especially at present in relation to the conveyance of disease.

But Lord Avebury by no means confined his attention to biological studies. He was an expert on banking; he was the first president of the Institute of Bankers, president of the London Chamber of Commerce, and for twenty-five years. he was secretary of the London Bankers Association and president of the Central Association of Bankers. For five years he was president of the London Chamber of Commerce, and he published important treatises on coins and currency, and on municipal and national trading. His was a very steadying influence on the commercial world. Without having the dominant influence of a Pierpont Morgan, or the great American banker's. power of handling a financial crisis, he had an infinite capacity for mastering detail, and a great gift for bearing in mind many things of importance which are apt to be overlooked in the ordinary course of business.

Lord Avebury took much interest in municipal government, and was vice-chairman of the London County Council in 1889 and 1890 , and chairman from 1890 to 1892 . Nor must it be forgotten that he was principal of the London Working Men's College, and did most admirable work in connection with that institution. His "Hundred Best Books" was the result of a lecture delivered at the college.

Few men have attained eminence in so many subjects, an eminence which would satisfy many a specialist. Part of this eminence was due to a gift of style. An American con"emporary once described him as an "elegant British writer on bugs." Even his most strictly scientific monographs were written in an engaging manner, and none more so than his "Origin of Civilisation and the Primitive Condition of Man," which is now in its sixth edition. Perhaps of his scientific works "The Scenery of England" and "The Scenery of Switzerland" are the most enduring. The former is still recommended by the teachers in many a university as a most admirable introduction to the study of geology. He seemed to have an instinct for knowing "what the public wants," and his more popular literary works appealed widely to "the man in the street." "The Pleasures of Life," "The Use of Life," "The Beauties of Nature," sold by the hundreds of thousands-in fact, a quarter of a million of "The Pleasures of Life" have already been disposed of, apart from more than forty foreign editions. These books, though they partake of the nature of reprinted commonplace books, certainly hit the popular taste, and were in their influence wholly healthy and helpful.

In our restricted columns it would be impossible to enumerate the numerous associations over which Lord Avebury presided. He was, indeed, to paraphrase an Elizabethan phrase, "President General to the Age." He was president of the British Association in its jubilee year, and president of the Entomological, Ethnological, Linnean, Statistical, African, and Ray Societies; president of the Anthropological Institute, of the International Institute of Sociology, and of the International Association for Prehistoric Archæology; of the International Association of Zoology, and of the

NO. 2275 , VOL. 9I] 
International Library Association. Here, again, our space forbids us to catalogue his almost inexhaustible list of honours, but we must mention that he was a Commander of the Legion of Honour, and he held the Order Pour le Mérite. He was elected a Fellow of the Royal Society in 1858 .

Lord Avebury married firstly Ellen, only child of the Rev. Peter Hordern, and secondly Alice Augusta Laurentia, daughter of the late General A. A. L. Fox-Pitt-Rivers, a granddaughter of the second Baron Stanley of Alderley. He is succeeded by his eldest son, the Hon. J. B. Lubbock, who is a partner in the banking firm of Robarts, Lubbock and Co.

\section{PROF. J. T. NICOLSON.}

THE early death of Dr. J. T. Nicolson, professor of mechanical engineering in the Manchester School of Technology and in the University of Manchester, will be much regretted by a wide circle of friends. His health during the past six months had given serious cause for anxiety, but had improved sufficiently to allow him to return to his duties. There followed a sudden relapse, and he died at Macclesfield on May 27 after a brief illness.

Prof. Nicolson was born at Amble, in Northumberland, in 1860 , and received his early education at Watson's College, Edinburgh. He was then apprenticed to Hawthorne Leslie and Co., Newcastle-on-Tyne. From there he gained a Whitworth scholarship and entered Edinburgh University, where he graduated in I889, obtaining the D.Sc. degree some years later. After graduation he spent two years in Charlottenburg, where he investigated the strength of materials under Prof. Martens. After holding the position of assistant-lecturer in engineering in the University of Cambridge, he was appointed in I892 professor of mechanical engineering in McGill University, Montreal. He took an active part in the equipment of the engineering department and in arranging the courses of instruction for students. During his stay in Montreal he undertook an investigation with Prof. Callendar on the valve-leakage of steam on the surface of cylinders. This important investigation led to the award of the Telford premium to the authors. Prof. Nicolson resigned his professorship in Montreal in 1899 in order to take charge of the engineering department of the School of Technology, Manchester, and was largely responsible for the whole engineering equipment of that institution-an equipment which in variety and extent is even now unsurpassed in this country. When degree courses were instituted in the School of Technology in connection with the University of Manchester he was appointed the first professor of mechanical engineering, a position which he held until his death.

Prof. Nicolson's tenure of the chair at Manchester was marked by several important and extensive investigations. He made detailed experiments on rapid-cutting steels, in which he showed the relations between the cut and speed and the durability. The results of these investigations were published as a report by the Manchester Association of Engineers in 1903, and were well received by the engineering profession. As was characteristic of Prof. Nicolson, he immediately applied the experimental results to the improvement of the design of machine tools.

During the last few years of his life he took up the question of the transfer of heat to boilers. The late Prof. Osborne Reynolds had predicted in 1874 on theoretical grounds that the rate of transfer of heat from a gas or fluid to a solid surface should increase with the velocity of movement. This was confirmed for fluids by the experiments of Dr. Stanton in 1897 . Prof. Nicolson, in an elaborate series of experiments, showed that the same result held for gases. He then applied this idea to the design of boilers and condensers, the essential point being that the heated gases were driven at a high speed through the tubes of the boiler, the water circulating in the opposite direction. As a result of an extended trial of a 6o-h.p. boiler over sixty days, it was found that the efficiency of such a combination was considerably greater than that of the ordinary boiler. There has been much difference of opinion among engineers as to the practicability of this idea, but Prof. Nicolson himself had the strongest belief in the greater overall efficiency to be obtained by his methods.

The training of Prof. Nicolson fitted him admirably to fill the position of a professor of engineering, for he had not only a wide scientific outlook, but took a keen interest in the practical side of his profession. This is shown by the promptness with which he applied the results of his scientific investigations to the improvement of engineering practice. He was a man with strong opinions on engineering questions, and vigorously supported his position when attacked. His personal integrity, straightforward character, and sympathy with their scientific difficulties endeared him to his colleagues, while his vigorous personality and ability as a teacher made a strong and lasting impression on all his students. Owing to his increasing deafness he was unable in recent years to take that active part in administrative matters for which his wide outlook well fitted him. His premature death is a great loss to science, and will be much regretted by his colleagues both in Manchester and Montreal.

\section{NOTES.}

THE home list of honours conferred on the occasion of H.M. the King's birthday on June 3 includes three new Privy Councillors, seven new baronets, and twenty-six knights. The only fellow of the Royal Society in the list is Prof. E. A. Schäfer, professor of physiology in the University of Edinburgh, who has received the honour of knighthood. The same honour has been conferred upon Prof. J. H. Biles, professor of naval architecture in the University of Glasgow. Prof. T. H. Middleton, formerly professor 